Anastasiya Fiadotava*

\title{
"We came for the Sluts, but stayed for the Slutsk": FK Slutsk Worldwide Facebook page between ironic and genuine football fandom
}

https://doi.org/10.1515/humor-2021-0007

Received July 28, 2020; accepted February 24, 2021;

published online March 24, 2021

Abstract: In spring 2020, with most national football (soccer) leagues being suspended, fans from around the world turned to the Belarusian Premier League Europe's only championship to continue amid the COVID-19 pandemic. In March, a group of Australian football fans created the FK Slutsk Worldwide Facebook group, dedicated to the eponymous Belarusian club, which quickly transformed into a diverse online community. Initially, the group demonstrated many features of ironic fandom, with members producing various humorous forms and performing exaggerated loyalty in recognition of the peculiar circumstances behind the intense international focus on an otherwise unremarkable team. As time passed and the Facebook group community evolved, however, the practices of ironic fandom began to give way to attributes of a genuine fandom. Through an examination of the group's development, this paper makes a case for viewing the relationship between ironic and genuine fandom not in oppositional, but in temporal terms. It argues that, in order for a fandom to sustain itself, it must be rooted in a shared sensibility that is not limited to a sense of irony, and that a transition from ironic to genuine fandom stems from this sensibility taking precedence over the ironic aspect.

Keywords: community; football; humor; ironic fandom; online

\section{Introduction}

In spring 2020, as nations across the globe were imposing social distancing and lockdown measures amid the rapidly unfolding COVID-19 pandemic, the Eastern European Republic of Belarus became something of an outlier, with President Alexander Lukashenko playing down the threat of the coronavirus and refusing to

*Corresponding author: Anastasiya Fiadotava, Department of Folkloristics, Estonian Literary Museum, 42 Vanemuise Str., Tartu, Estonia, E-mail: anastasiya.fiadotava@folklore.ee 
implement a lockdown. This affected various spheres of life, including sport. As a result, when national football (soccer) leagues around the world were cancelling matches and suspending their seasons, the Belarusian Premier League remained the only European championship still playing, attracting attention from football lovers worldwide.

On 23 March, 2020, a group of Australian football fans created the FK ${ }^{1}$ Slutsk Worldwide Facebook group, dedicated to the eponymous Belarusian football club. The group reached 7,000 members in less than two months, quickly transforming into a diverse and multi-faceted online community, which, moreover, was being covered by major international media outlets such as the BBC and the New York Times. The sudden international interest was unprecedented both for the club, which debuted in the country's top league in 2014 and has never finished a season higher than in seventh place, and the Belarusian Premier League itself, ranked by the Union of European Football Associations 32nd out of 56 member leagues based on its clubs' performances in the past five years.

While the factors leading to the group's emergence are themselves noteworthy and emblematic of the unprecedented effects that the COVID-19 pandemic had on global sports fandom, what is particularly remarkable is the temporal dynamic displayed by the posts and comments in the group. Initially, many of the group members recognized the peculiar circumstances behind the intense international focus on an otherwise unremarkable team, producing a variety of memes, jokes and other humorous forms playing around the exaggerated loyalty of fans to their new favorite club; its name, which evokes particular connotations to English speakers; and the very fact that the Belarusian Premier League continued despite the COVID-19 outbreak. However, as time went by and the inter-group relations and the external circumstances were evolving, the focus on the inherent humorousness of the situation became less articulated and gave way to other, more conventional aspects of online football fandom such as mobilizing support for the team ahead of each game and celebrating individual players' contributions.

The evolution of communication in the FK Slutsk Worldwide group offers an intriguing perspective on the temporal dynamics of humor ${ }^{2}$ (and, in particularly, irony) in sports fandom. What started out as a clear case of "ironic fandom" (Bekkering 2016, 2018) gradually shed many of its overtly ironic features and morphed into more of a conventional fandom, while retaining much of the group identity and the content generated there.

1 "FK" is a transliteration from the Belarusian acronym for futbol'ny klub (football club).

2 This paper uses "humor" as an umbrella term that encapsulates a broad range of phenomena, including irony, sarcasm, as well as affiliative humorous banter (on the use of "humor" as an umbrella term, see Martin and Ford 2018: 11). 
By examining the temporal transformation of the content posted in the group, this article aims to contribute to the emerging body of research into the phenomenon of ironic fandom. Through an analysis of the posts and comments contributed by FK Slutsk Worldwide users, I will address the central question driving this research: how, and why, does online ironic fandom emerge, evolve or fade away over time?

\section{Theoretical background and literature review}

The present paper draws upon existing scholarship on ironic fandom and online football fandom. With the advancement of mass and social media, the fandoms of popular clubs have become global, with many of the fans' activities increasingly taking place online. It is now next to impossible to be an active football fan without engaging in online activities (Ruddock et al. 2010: 325). Apart from official websites and social media groups, many top football clubs have fan-run pages and groups on social media, where members share information about their favorite club and socialize (for an in-depth discussion, see Rivers and Ross 2019: 3). These groups often have followers from all over the world who may never meet in person, and the only thing that unites them is their shared support of a certain club.

Online participatory media (Howard 2008) have marked a shift in how sporting celebrities interact with their fans. Traditional media allowed their audiences to build parasocial interactions with famous athletes, whereby the perceived interaction between the fans and the athletes was largely mediated and one-sided. Despite the asymmetry, such parasocial relationships helped increase the audience's engagement with and positive perceptions of the various elements that relate to the athletes' identity, such as their team, the brand they advertise, etc. (Spinda et al. 2009). By contrast, online media have enabled a more direct conversation between athletes and their fans (Frederick et al. 2012). For many fans, this has deepened their sense of belonging to a community (Yuksel and Labrecque 2016), even if in the case of many top clubs and celebrity athletes, direct engagement with fans is infrequent. In these cases, parasocial relations constitute the norm that is accepted by the supporters, who do not expect an explicit response beyond the occasional broad and anonymous acknowledgement, such as when a manager thanks the fans for their support during a post-match conference.

In addition to increasing the immediacy of athlete-fan communication, online media have also facilitated fans' production of their own content as part of their fandom (Benigni et al. 2009). This aspect of participatory culture (Jenkins 2006) makes football fan groups on social media an engaging and creative space for interaction. Similar to other kids of fandom, for football fans the pleasure of 
watching the favorite team play is supplemented with the pleasure of engaging in conversation with like-minded individuals, expressing their views on players and coaches, predicting the results of future fixtures, etc. (Whetmore and Kielwasser 1983, cited from Baym 2000: 14; Cleland and Dixon 2015), and online communication increases the immediacy of such conversation and magnifies its reach.

Using humor in online fan communication often lends further engagement to the experience and receives a positive response from fellow members of the online community (Kytölä 2012: 239). While humor can sometimes be used by football fans to downplay serious issues and thus be condemned by other members of fan communities (Jones 2008: 528), it can also take the more socially acceptable form of irony and banter (Rivers and Ross 2019).

Previous research on the use of humor mostly discussed genuine football fandoms, which combined serious and often long-term support of a favorite team with humorous elements of communication aimed at the team or the fans themselves (for a prominent case in point, see Bell et al. 2020). However, little attention has been paid to the football (or any sports) fandoms that were initially intended to be humorous by their creators (except for a brief mention in Dyal 2012: 78).

The framework of "ironic fandom" is a useful methodological tool to explore such phenomena. The notion has mostly been applied to popular media fans and fake religion followers (Ang 2006; Bekkering 2016, 2018; Edwards 2007; Thomas 2009; a related but distinct concept is that of "critical fandom," see Haig 2014). In studies of media fandoms, ironic fans are often juxtaposed with "real" ones, the former mostly "deriv[ing] unintended pleasure from what they consider[] a 'bad' mass cultural product” (Bekkering 2018: 21). However, ironic and genuine fandom can also intertwine, especially when the fandom practices become a part of broader social interactions (Ang 2006: 195). Ironic fans can still demonstrate a genuine admiration for their “idols" (Bekkering 2016) and combine an ironic attitude with emotional engagement, oscillating between humorous and serious modes of discourse depending on the circumstances (Thomas 2009: 60).

Research into ironic fandom has mostly focused on how irony helps to maintain critical distance between fans and the object of their fandom (Bailey 2005: 192-193; Skey et al. 2016), including in cases where the fandom focuses on what is perceived to be "bad quality" cultural product (Haig 2014; Turner 2016). However, the temporal dimension of ironic fandom has largely been overlooked. And yet, temporality is an important aspect of any activity involving humor, as humor feeds on novelty and surprise (Berlyne 1972: 58). This paper aims to fill this gap and analyze the temporality of ironic fandom in an online environment. Through a case study of FK Slutsk Worldwide Facebook page, it aims to serve as a starting point for a broader discussion on how the role of humor and irony evolves 
over time in an online fan community, and how this evolution affects communication and activity in the community.

\section{Methods and data}

This research is a case study, based mainly on a corpus of posts collected by the author from the FK Slutsk Worldwide Facebook page. Overall, I analyzed over a thousand posts and comments dating between March 23, 2020 and July 9, 2020. My initial focus was primarily on the humorous content, which I found to be prevalent in the early weeks of the group's existence. I considered posts and comments to be humorous when they received multiple "Haha" reactions on Facebook; when fellow group members' responses to them displayed a humorous reception; and, in some cases, when they were based on established templates used to create humorous memes.

Much of the humor was (audio)visual: during this period, the group members shared 310 items of audiovisual humor, 10 of which were videos and 300 were images (mostly images with captions, or image macros ${ }^{3}$ ). Other genres of humorous folklore were considerably less popular: I counted seven canned jokes, three personal humorous narratives, a humorous survey, and a humorous slogan. Besides these easily identifiable genres, humor was also often present in comments to the posts (humorous and serious alike), sometimes resulting in long threads of humorous banter.

The data were subjected to qualitative content analysis. I coded the data according to the topics (e.g., COVID-19, FC Slutsk's club name, club fans, etc.) and genres (humorous video, image macro, joke, etc.) to which they belong. For visual data, I applied multimodal analysis, drawing on Yus's (2019) cyberpragmatic approach; this involved taking into consideration both the visual and textual components, as well as the interrelation between them. My analysis of the individual humorous items was not limited to the content of these items in isolation; rather, it was informed by the overall discussion in the group. Since the focus in this paper is on the temporal aspect, an important consideration in analyzing each post was at what point in the group's existence it was published, and what else was being posted in that period of time. This was the basis for me identifying three main (albeit fuzzy and overlapping) stages in the group's development, according to which my analysis below is structured.

My analysis was also informed by publications about the Facebook group in the media. I was particularly interested in the vernacular reflections of the group's

3 For a discussion on image macros, see Dynel (2016). 
founders and members on their support of FC Slutsk. In addition, I also studied the official FC Slutsk social media groups on $\mathrm{VK}^{4}$ and Facebook.

As is inevitable in interpretive research, my analysis resulted from my subjectivity as a humor researcher, a folklorist, and as a Belarusian; following Sullivan (2002), I consider this subjectivity to be an asset that helped me embrace open interpretations rather than reductive, decontextualized readings of texts.

\section{Analysis: FK Slutsk Worldwide through a diachronic lens}

\subsection{The backstory}

In order to analyze the content posted in FK Slutsk Worldwide and its theoretical implications, it is important to consider the peculiar context in which the Facebook group came to be. This context not only explains the unlikely emergence of an international fandom for an unremarkable football club in a little-known national league, but it has also been continuously reflected upon and negotiated by the group's members, as will be shown below.

The COVID-19 pandemic and the resulting cancellation of all major football leagues in spring 2020 presented a challenge for football fandoms around the world, which suddenly found themselves deprived of the opportunity to do the one thing central to their identity as fans: support their favorite clubs in competitive matches (Waliaula and Okong'o 2020). While many online communities dedicated to top football clubs continued to thrive, they had to adapt to the new circumstances and maintain the fans' morale even in the absence of actual football. The temporary cancellation of football matches did not prevent the fans from supporting their favorite teams and expressing this support online, but they longed for watching and discussing real football games, especially as many of them had to spend much time at home.

This is where the Belarusian Premier League and FC Slutsk in particular came into play. At a time of lockdown, any ongoing professional sporting event is likely to attract intense media attention (Parnell et al. 2020: 5), which, in turn, stimulates the interest of supporters. This is exactly how a group of Australian supporters came across FC Slutsk, which FK Slutsk Wordwide founder Shane Robinson relates thus: "One of the boys was on a betting website and came across this Belarusian Premier League that was still going. We just chose the first team that was playing

4 VK is a social network similar to Facebook, popular among Russian speakers. 
that night, which was Slutsk, and it's kind of taken up from there" (quoted in McCormack 2020). After watching Slutsk play via an online stream, the group decided to create a Facebook group dedicated to the club. Within days, the group was receiving attention from football fans around the globe, reaching 7,000 members in under two months and landing Robinson interviews with both Australian and international media. Commenting on the group's unexpected popularity, Robinson said: "It's been absolutely insane. We started it as a small group to have a few laughs, a bit of a chat, find a few ways to watch the games" (quoted in McCormack 2020).

It is evident from this account that, at its inception, the group bore humorous undertones. This is also clear in the content that was being posted in the group in the early days of its existence.

\subsection{Early days: the novelty stage (late March-mid-April 2020)}

As the group started to get traction, its administrators took on the responsibility for providing opportunities for newcomers to engage in supporting FC Slutsk. The administrators would post links to live streams of upcoming matches, while members discussed the team's lineups, the betting odds for each game, and shared other content, including humor. During the games, group members posted photos of themselves watching FC Slutsk playing and commented on the key moments in the games. It is difficult to estimate exactly how many of the Facebook group's followers engaged with the football team's performance (rather than just the humorous banter in the group), but during each match, several dozen fans would leave comments and posts related to the team's performance on the pitch.

During the first weeks of the group's existence, the incongruity of an international online fandom for a previously unknown local club was explicitly and implicitly present in many FK Slutsk Worldwide posts, accounting for a significant number of humorous items that were created and shared by the group members. In the absence of shared experiences and long-standing humorous tropes, most of the humor was produced in a way that would make it easily understandable to all members and would not require much contextual knowledge (cf. Adetunji 2013: 159 on the metaphorically coded teases of a long-term fandom).

A major subject of discussion in the group was the name of the club itself. While the name of the town of Slutsk (the club's namesake) is pronounced as slootsk, its spelling resembles the English word "sluts"; and English speakers

5 https://www.facebook.com/photo.php?fbid=10222172817728459\&set=gm.246919653156049\& type $=3 \&$ theater\&ifg $=1$. 


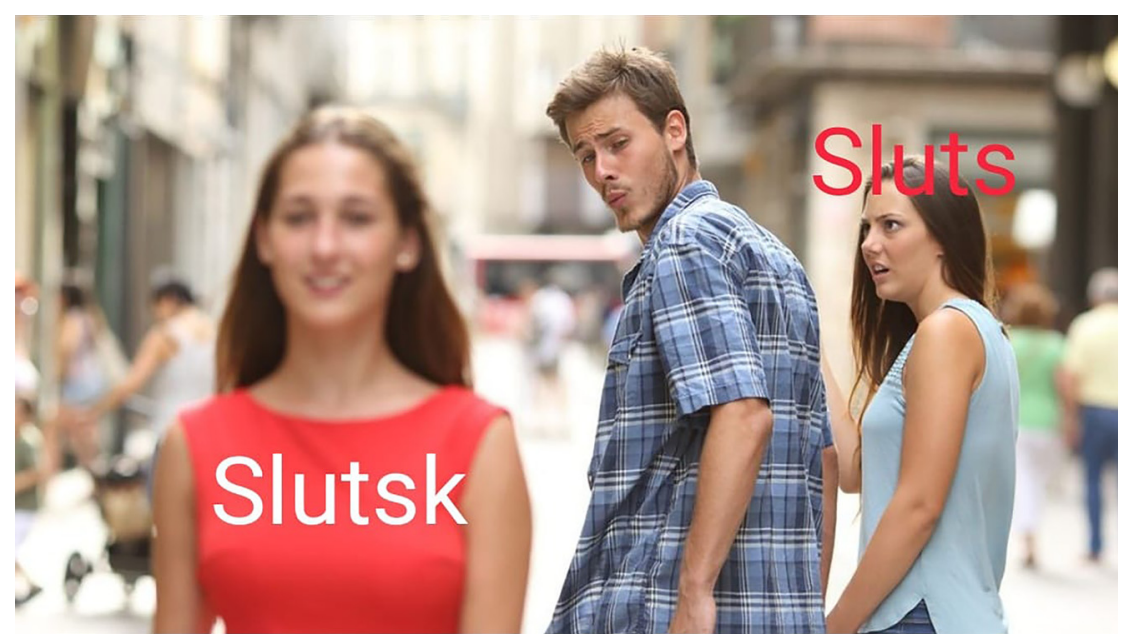

Figure 1: Image macro based on wordplay. The image is a popular "Distracted Boyfriend" meme template that locates the image macro within the trends of online communication. ${ }^{5}$

unfamiliar with Slavic languages may assume the words are pronounced similarly as well. According to some of the Facebook members' posts, this resemblance was what initially attracted them to the group. Naturally, it also inspired a lot of humor that plays with the similarity between "sluts" and "Slutsk," as well as the preference of the latter over the former at the times when top football leagues are not available (Figure 1).

The name "Slutsk" may also evoke other associations for football lovers, namely, with Russian football coach Leonid Slutsky, formerly the head coach of the Russian national team and FC CSKA, one of the leading clubs in Russia. International FC Slutsk fans suggested that Slutsky should be involved in coaching the club and created humorous image macros playing with the similarity between his name and the name of the club. From there, the humor was picked up by different parties. On April 10, Leonid Slutsky was interviewed by YouTube vlogger KraSava (КраСава). ${ }^{6}$ One of the topics that they discussed was FC Slutsk and its upcoming match against a team from Vitebsk. Leonid Slutsky delivered a mock pep talk, humorously suggesting a starting line-up and giving instructions to the players as if actually coaching the team. The speech inspired several humorous

5 https://www.facebook.com/photo.php?fbid=10222172817728459\&set=gm. 246919653156049\&type=3\&theater\&ifg $=1$.

6 The video is available here: https://www.youtube.com/watch?v=f4IkvZoIB4Q, accessed on June 8, 2020. 


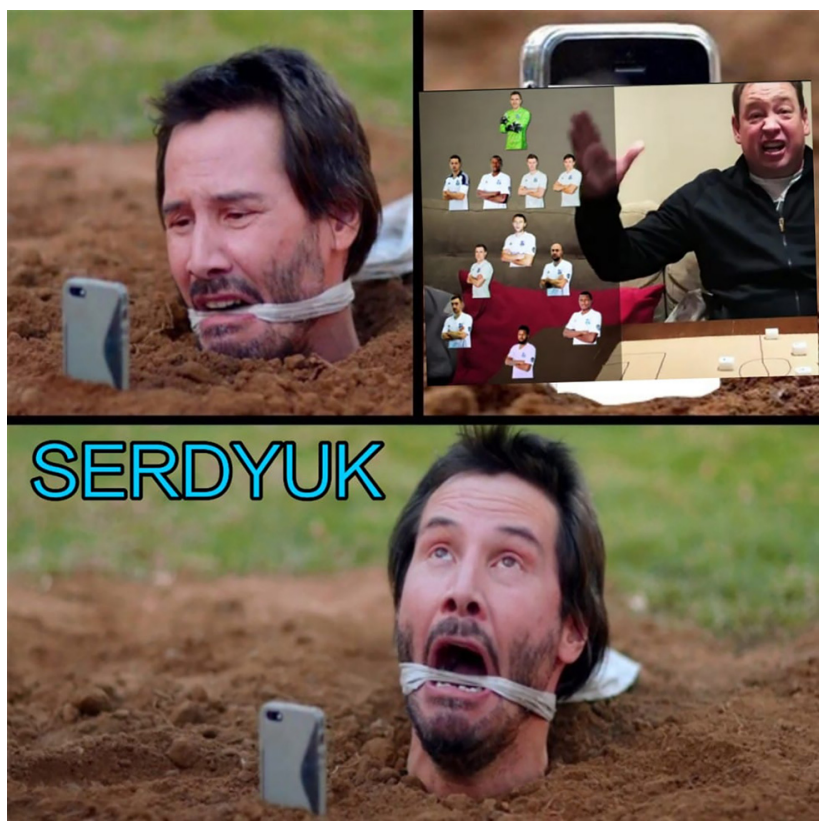

Figure 2: Leaving Serdyuk out of the starting line-up. ${ }^{7}$

image macros created by FK Slutsk Worldwide followers. One of them, for example, revolved around the fact that in his mock pep talk Slutsky did not include Artem Serdyuk (one of the most beloved FC Slutsk players among the international supporters) in the starting line-up (Figure 2). This example already hints at the trends that become more visible during the next stage, namely, the close following of FC Slutsk-related media and the need to have contextual knowledge to understand the humor of the group.

Another topic that featured prominently during the first weeks of the group's existence is the comparison and contrast between FC Slutsk and world-famous football clubs. As humor is often used in football fans discourse to negotiate the serious implications of discriminatory expressions (Rivers and Ross 2019: 5), some world-famous players would be unfavorably compared to those representing FC Slutsk (Figure 3).

Emblematically, many of the earlier examples of humor in the group referred to the unprecedented situation where famous football clubs and players had to stop playing football while FC Slutsk continued to play. Sometimes the fans would

7 https://www.facebook.com/photo.php?fbid=582409415815748\&set=gm.

254166642431350\&type $=3 \&$ theater\&ifg $=1$. 


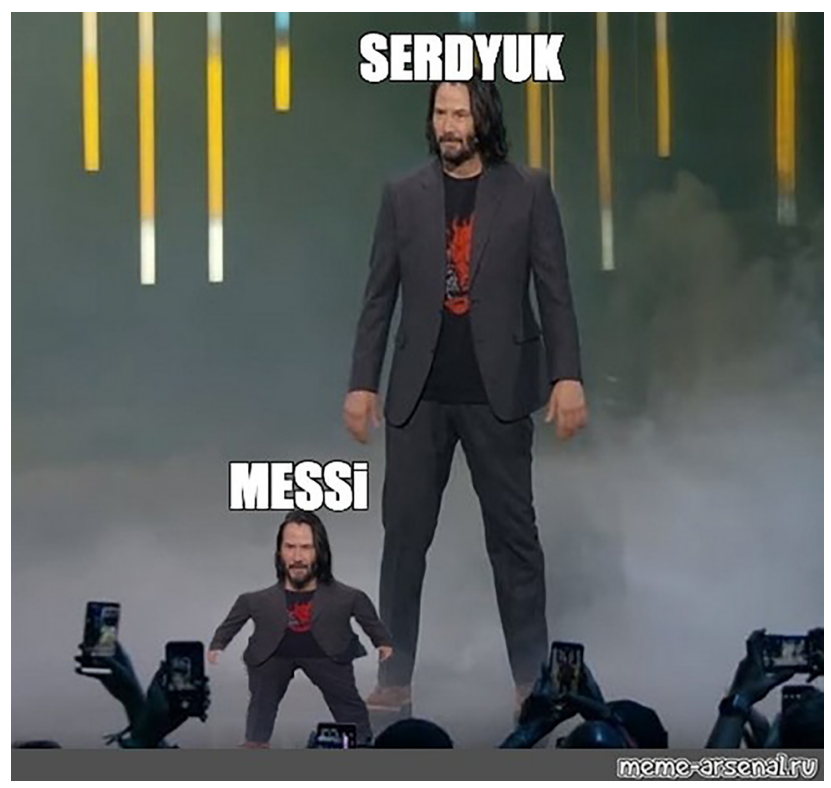

Figure 3: Comparing FC Slutsk players to world-famous players such as Lionel Messi. ${ }^{8}$

digitally manipulate the photos of top football players by replacing their faces with the faces of FC Slutsk players who play in a similar position or share a visual resemblance to them, or adding the FC Slutsk logo to the images.

While the posters themselves did not explicitly reflect on their intentions when drawing parallels between FC Slutsk and world-famous clubs, there is a number of possible interpretations of this trend, which are not mutually exclusive. One is that, by continuously invoking major football celebrities in the group discussion at a time when none of them were playing, fans sought to cushion the drastic change in the content of their football consumption and fandom amid the COVID-19 pandemic. Hyperbolizing FC Slutsk players' ability and prominence by comparing them to the likes of Messi and Ronaldo also served as a tongue-in-cheek acknowledgement that the fans themselves did not take the club's newly found fame too seriously. At the same time, it is possible that discussing Slutsk players and coach on the same terms as their world-famous counterparts served to rhetorically elevate the status of the former, thereby helping legitimize the FC Slutsk fandom as such.

8 https://www.facebook.com/photo.php?fbid=2744602875593191\&set=gm. 247773936403954\&type=3\&theater\&ifg $=1$. 
Reflection on the community itself was indeed pervasive in the group, with much of it humorously addressing the group's spontaneous emergence and lack of established traditions and history - things highly valued in conventional football fandom (Parganas et al. 2015). The following ironic remark is a good example, highlighting the implicit tension between the group's brief existence and its members' budding sense of belonging: "As a lifelong Slutsk fan of eight days now, I can safely say this is not a fleeting love.”

Given the peculiar circumstances that gave rise to the worldwide support of FC Slutsk, the group members also discussed whether this support would continue after the end of the pandemic. While many of these discussions were serious in tone, humorous comments were also frequent. The use of humor in this context helped sidestep the sensitive question of whether the fans would continue to follow FC Slutsk's performance after the pandemic, creating a sense of ambiguity about the future of the club's international fandom (Figure 4).

\section{"Slutsk will have \\ no fans once the virus ends"}

\section{5 - Me and the boys arriving at Minsk away}

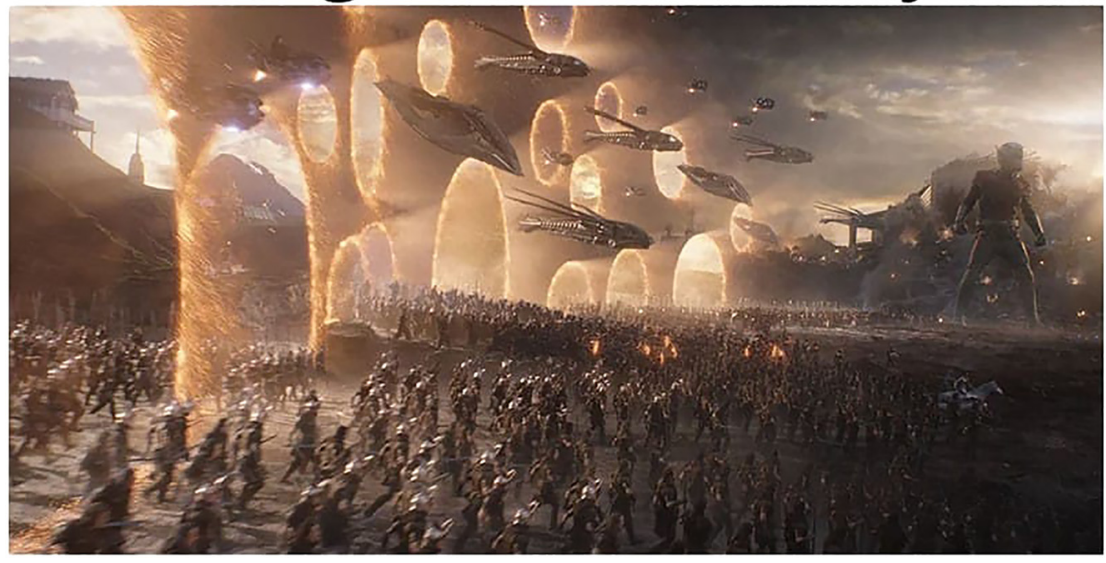

Figure 4: Discussion on the post-pandemic future of FC Slutsk fandom. ${ }^{9}$

9 https://www.facebook.com/photo.php?fbid=3328390413872521\&set=gm. 248176153030399\&type $=3 \&$ theater\&ifg $=1$. 
A smaller thematic group of humorous items that appeared in the group in this initial period refer to the COVID-19 pandemic and the ways in which it impacted world (and Belarusian) football. Some of them refer to the Belarusian president's (presumably humorous) suggestion that vodka and sauna can help prevent the spread of coronavirus. ${ }^{10}$ The incongruity of Belarusian football leagues continuing to play amid a pandemic did not escape the group members' attention either. The fans even jokingly suggested that the pandemic had been orchestrated by the Belarusian Premier League to draw attention from football lovers across the world (Figure 5).

Despite the presence of COVID-19-themed posts in the group, they accounted for only a minor part of what was shared. This can seem striking, considering just how many jokes, memes and other humorous items related to the pandemic were spreading across social media in spring 2020. Yet, the group members' reluctance to discuss the pandemic is also understandable given the fact that the group was created to compensate for the lack of football action in other leagues and to help football lovers adapt to the new reality of the world. As such, FK Slutsk Worldwide might have become a space to escape reality and suspend fears and uncertainty that the pandemic brought. Through engaging in usual fan discussions and online activities, the group members were able to shield themselves from the otherwise pervasive subject of COVID-19, and even humor rarely penetrated this shield.

As the examples above illustrate, during this initial period the content posted in the group was not just largely humorous in nature, but much of it also displayed some degree of "ironic distance" and amusement, which are associated with ironic fandoms (Bekkering 2016: 139). Yet, despite the ironic undertones of the discussion in FK Slutsk Worldwide in these early weeks, FC Slutsk club management quickly recognized the group's potential and sought to capitalize on it. Just a few days after the creation of FK Slutsk Worldwide, the club created an official group on Facebook, with posts almost exclusively in English (in contrast to their long-standing Russian-language group on VK, aimed at local supporters). The club also regularly engaged in conversation with its newly found international fans on the FK Slutsk Worldwide fan group. While the club's side of the conversation was mainly serious in tone, they also contributed humorous content on occasion (Figure 6).

Also noteworthy was the conversation between the international fans in the group and its Belarusian members, who, while a minority, quickly grew to be a visible presence. From the early days of the group's existence, some of the international fans expressed interest in how the community was being received by local fans. Consider the following question, posted on April 2, 2020: "Does anyone know, are long time Slutsk fans happy about this new wave of fans from all corners

10 The suggestion was expressed at a president's briefing on March 16, 2020, see Aleksandr Lukashenko: Ya chelovek nep'yushchiy ... 2020. 


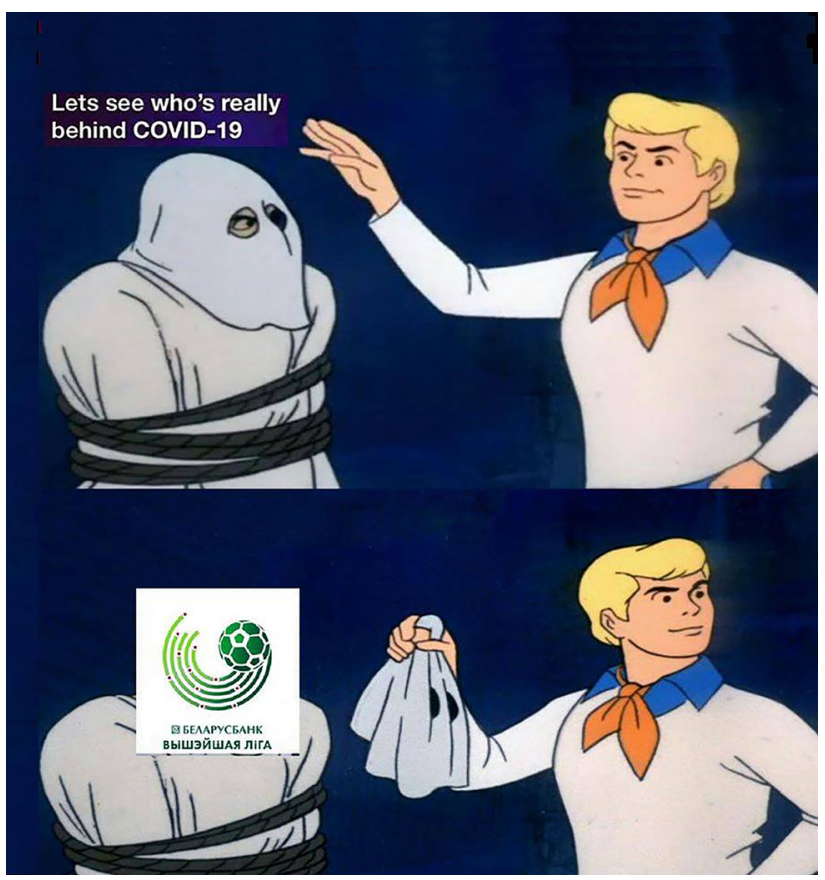

Figure 5: Commenting on the Belarusian league's continuation during the COVID-19 pandemic. ${ }^{11}$

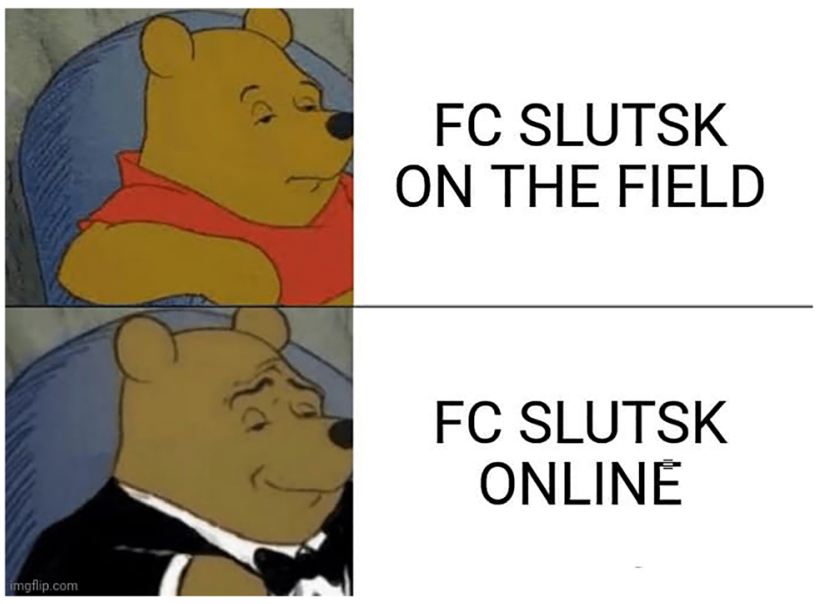

Figure 6: This image macro was contributed by the official FC Slutsk group. ${ }^{12}$

11 https://www.facebook.com/photo.php?fbid=10163227184135052\&set=gm. 248008343047180\&type $=3 \&$ theater\&ifg $=1$.

12 https://www.facebook.com/photo.php?fbid=117690489877557\&set=gm. 249395599575121\&type $=3 \&$ theater\&ifg $=1$. 
of earth?" The post received two replies, both of them assuring the author of Belarusians' positive attitude towards the initiative. One of the commenters offered a detailed response:

I am not a slučak [a person from Slutsk], but as a Belarusan, i am glad for several things.

More interest to the country.

Really good steps from the club to turn global trollying into a real worldwide community. It is not easy to accept the reality with humor, especially if your club belongs to such an oldschool management organisation as a sugar plant ${ }^{13}$ in Belarus. Real respect.

Try to organise global crowdfunding, as the guys are facing really bad times. ${ }^{14}$ It is a challenge to be discussed country-wide, as the example shows how Belarus is isolated from global paysystems.

This post demonstrates both the author's recognition that the international fandom for FC Slutsk originated at least in part as a joke ("global trollying") and their belief that the club's willingness to initiate a dialogue with its international fans could help it build a genuine international fan base and possibly overcome its financial struggles.

Overall, while not numerous, Belarusian members in FK Slutsk Worldwide were a diverse group. A few of them were long-time Slutsk supporters who contributed photos of themselves attending matches at the club's stadium; most, however, had not supported Slutsk before. Of the latter group, many mimicked the online behavior of international Slutsk fans by creating similar humorous content, while others saw the group as an opportunity to educate its international audience about Slutsk and Belarus, linking to numerous articles and videos on Belarusian history, music, etc. One member even offered to give free lessons of the Belarusian language to the group members. Many international Slutsk fans also gradually developed an interest in Belarus: not only did they begin to explore the Belarusian market in search of a possible sponsor for the financially struggling club, but they also shared links related to Belarusian culture and asked Belarusian members for recipes of typical Belarusian dishes.

Not all conversations between international and Belarusian members were equally amicable, however. In one of the comment threads, a Belarusian supporter started teasing an international fan because of the associations his name might

13 FC Slutsk's main sponsor is JSC Slutsk Sugar Refinery.

14 The comment refers to a crowdfunding campaign started by the FK Slutsk Worldwide group creators after they learned that the club was facing financial difficulties. The club management first suggested sending donations via bank transfer (which was inconvenient and costly for the international supporters), as global payment systems are not always accessible in Belarus. 
evoke in Belarusian. When confronted by fellow Belarusians, he explained that he began the teasing because the international fan was mocking the club due to the phonological similarity between the club's name and the word "sluts." Further, he accused the other Belarusian members of being subservient toward the international fans, hinting that they might be doing it in the hope of gaining a material profit. While not common, such examples point to a lingering tension between the group's ostensible status as a fandom and its ironic roots.

\subsection{Identity formation (mid-April-late May 2020)}

As the fans got to know each other better, communication between them began to transform. Some of the topics outlined above persisted, but the ways they featured in the FK Slutsk Worldwide Facebook group changed. For example, most of the humorous references to COVID-19 in the FK Slutsk Worldwide group date back to late March and early April when the Belarusian Premier League's continuation despite the continued spread of the virus was particularly striking. As the spread of the virus in Europe began to slow in May, and other leagues started reopening, the topic lost its appeal. Instead, serious discussion full of concern began when players of several other Belarusian clubs tested positively for COVID-19. Tellingly, many of the posters expressing concern over the players' wellbeing were the same "ironic fans" who just weeks earlier had been actively creating and sharing humorous content about FC Slutsk. One may speculate that, as the threat of Slutsk players contracting the coronavirus grew increasingly real and less psychologically distant, the norm violation - to use McGraw and Warren's theory (2010) became less benign and thus less likely to inspire humor.

Reflections on the group's recency and lack of established tradition likewise ceased to be a prominent thread in the discussion. So, for the most part, did ironic juxtapositions of FC Slutsk and major international football clubs. Instead, the group's humor grew increasingly rooted in the FC Slutsk's actual history and performances on the pitch.

A case in point is the proliferation of ironic image macros targeting the club's rivals and competitors in the Belarusian Premier League. Most of them were explicitly derogatory toward the other clubs and depicted FC Slutsk as a vastly superior side. As is common in traditional football rivalries (Benkwitz and Molar 2012), the disparaging humor in the group targeted not only the other clubs' players, but also their supporters. Some initial image macros in this vein were already posted in the early weeks of the group's existence, but they were not especially numerous and tended to be highly generic, whereby the rival's name could be replaced by any other team. Gradually, however, these image macros became more specific and reflective of individual clubs and their fans. 


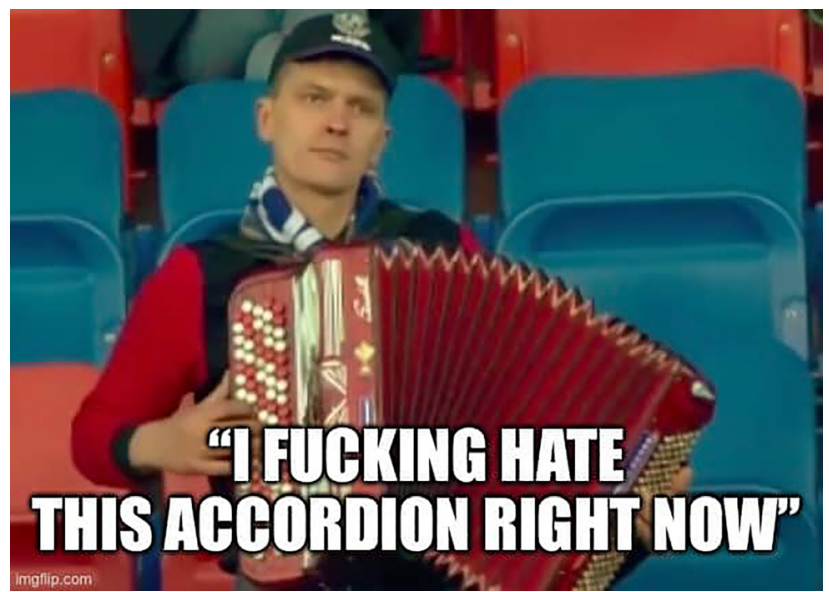

Figure 7: FC Isloch lost to FC Slutsk 1:2 at home. ${ }^{15}$

As is common with image macros, many of them used the same background images, thereby creating a continuity and establishing an in-group tradition. While some of these images were based on globally popular memetic images customized through the addition captions referring to FC Slutsk (on local adaptations of global memes, see Shifman 2014: 169; Shifman and Thelwall 2009), others used original images from the team's games. One example is based on FC Slutsk's away game at FC Isloch (resulting in FC Slutsk's victory), where one of the home club's supporters was spotted playing an accordion in the stadium. This inspired a number of humorous posts and discussions and for a brief period became one of the group's memes (Figure 7).

This shift from more generic content to content rooted in the common lore the group had developed during its short existence, indicates the emergence of a shared community identity beyond ironic amusement - a key feature in any fandom (Baym 2007). This identity was not only constructed through memes and Facebook comments, but also through community practices: football watching parties on Zoom and other videoconferencing platforms, creating a video remix of the club's unofficial English-language anthem (itself created by one of the group's members), and so on. As the group grew, there were also hints of smaller regional subcommunities budding, with members posting questions such as "Any Canadian fans on here?," “There are any Slutsk fans from Burkina Faso here?," etc. While the global pandemic was hardly a conducive setting for in-person get-

15 https://www.facebook.com/photo.php?fbid=10219272396579008\&set=gm. 250662799448401\&type=3\&theater\&ifg=1. 


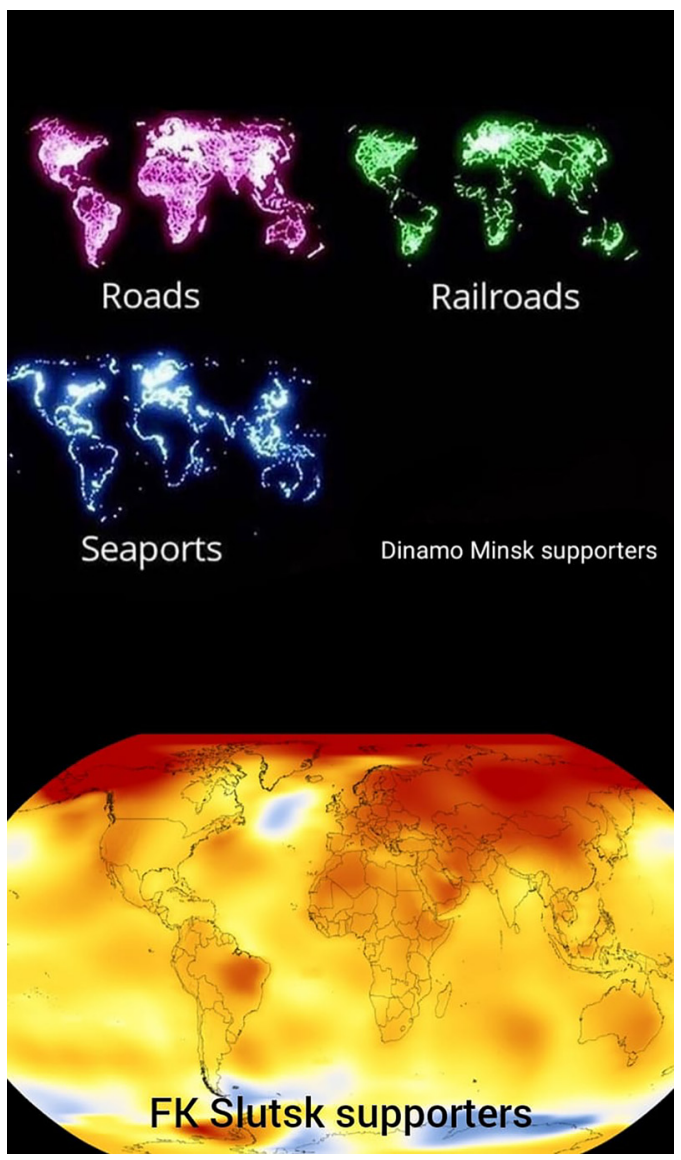

Figure 8: Highlighting the number of Slutsk supporters. ${ }^{16}$

togethers, some of the New York-based fans discussed plans to meet at a local bar after the end of the pandemic and watch football together.

The growing sense of FK Slutsk Worldwide coalescing as a community is also reflected upon in the humorous content targeting the group's members themselves. Compared to the displays of self-irony in the content from the group's early days, many of the newer posts were more personalized, featuring, e.g., a group member's face photoshopped onto an existing image macro. Whereas previously the group's posts might have played with the relative obscurity of both FC Slutsk and its international fandom, now they were more likely to highlight - in typically hyperbolized fashion - this fandom's global reach (Figure 8).

16 https://www.facebook.com/photo.php?fbid=2841289379321538\&set=gm. 269522180895796\&type $=3 \&$ theater\&ifg $=1$. 
Belarusian group members continued to communicate with the international fans; however, here, too, the dynamic had changed. Whereas in its early days, few of the Belarusians that the group attracted were actual Slutsk fans, eventually, long-time supporters of the club became a prominent voice in the community. Expressing appreciation for the club's newly-formed international fandom, many of these local fans sought to contribute by sharing photos of the club stadium, player dressing rooms, and their supporter kits - things most international fans did not have access to. Sometimes, the appreciation for the international fandom was mixed with a tinge of disbelief as, for example, was expressed by a Belarusian group member in one a comment addressing a Kazakh FC Slutsk supporter who had created and posted numerous humorous image macros to the group: "You are a funny guy ... You spend so much time on our kolkhoz ${ }^{17}$ Slutsk. Respect to you. Incredible times. You will, of course, remain in Belarusians' memories for a long time.)) Thank you! [in Belarusian] ${ }^{18 ”}$ (May 26, 2020).

The communication between the fans and the club itself also reached a new level. The FC Slutsk public relations team arranged several Q\&A sessions with some of the players, inviting the international supporters to submit their questions and then livestreaming the responses on Facebook. Further still, the players themselves began to communicate with their international fans directly, despite the language barrier and the time difference. Some of them also used humor in their communication with the fans. Forward Artem Serdyuk, who had become one of the most popular players among the club's international fans, often replied to fans' posts featuring him. When one of the fans posted a short video clip of him exercising before the game under the title "Artem doing his impression of Let's Twist Again ...," Serdyuk replied: “dancing dancing ordered? 6 (6), referring to the international fans' request for the club to come up with a distinct goal celebration. Indeed, in their next game, the FC Slutsk players performed a "kangaroo goal celebration" as a tribute to their Australian supporters (Figure 9).

However, as time went by and the novelty wore off, this ironic aspect, too, became less pronounced, with fans increasingly focusing on the club's performances and overall situation, leading to the Facebook group increasingly resembling a genuine fandom. A comment by one of the group members sums it up: "We came for the Sluts, but stayed for the Slutsk."

17 The word "kolkhoz" (lit. collective farm at the time of the USSR) is often used as a derogatory epithet to denote something that is considered backward.

18 Except for the final "Thank you" the comment was written in Russian and translated by me. 


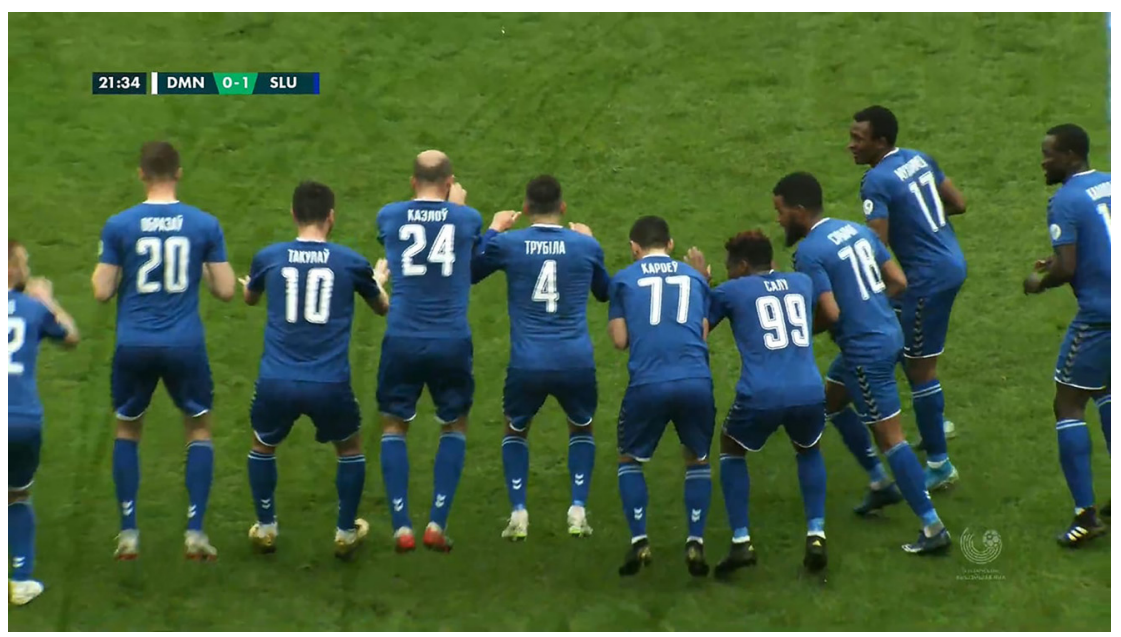

Figure 9: Kangaroo goal celebration. ${ }^{19}$

\subsection{The aftermath: beyond ironic fandom (since late May 2020)}

While humor was a very prominent part of the discussion in the FK Slutsk Worldwide group during the first months of its existence, it became less visible in late May and June 2020. This can be explained by several reasons. First, the international popularity of the club and international fans' activities on Facebook have generally declined. FC Slutsk's performances worsened compared to the previous months when the club was seen as an underdog punching above its weight: now, most of their matches resulted in either draws or defeats. Coupled with the return of many top European leagues and the easing of lockdown restrictions, this spelled a decrease of attention towards FC Slutsk. The perceived humorousness of the idea of large international support for a small local club had, too, by now faded away. Some of those who had joined the group "just for fun" stopped following it actively as it did not provide constant and varied amusement: the jokes about FC Slutsk's name and its superiority over the world's top football clubs had grown stale, and these members were not sufficiently invested to be able to follow the in-group jokes of the later period.

Other members, however, continued following FC Slutsk's progress and posting in the Facebook group (mostly on match days), expressing their joy when the club scored or won and bitterly discussing their losses - just as they would

19 https://www.facebook.com/photo.php?fbid=10217045888441246\&set=gm.

269837757530905\&type=3\&theater\&ifg=1. 
have done on their favorite club's page before the pandemic. The official FC Slutsk Facebook group also continued to provide the information on the match line-ups, game results and other club's activities to their international followers. Ironic fandom turned out to be a short-lived phenomenon: it has partly transformed into a bona fide fandom, and partly faded away.

The trajectory of the FK Slutsk Worldwide group displays three relatively distinct stages: the novelty stage, the stage of group identity formation, and the transition to a bona fide fandom (which ultimately involved only a part of the group's initial membership). This transformation is indicative of an inherent tension at the heart of an ironic fandom. On the one hand, such fandoms stem from a place of amusement at and ironic distance from their subject. On the other hand, any fandom relies on fans' attachment to its subject and a shared sense of intimacy both between the fans themselves and the people they are fans of (McCormick 2018). In other words, a shared sense of irony alone is not enough to sustain a fandom in the absence of a shared appreciation for something else about its object, especially as humor relies on novelty, which the same limited set of signifiers is unlikely to continuously provide.

Previous scholarship on ironic fandom has touched upon the permeable boundaries between ironic and genuine fandoms (Bekkering 2016, 2018). The case of FK Slutsk Worldwide further problematizes this boundary, suggesting that the relationship between ironic and genuine fandoms may be considered not in oppositional, but in temporal terms. That is to say, what emerges as an ironic fandom may need to establish a shared community identity and develop a sense of appreciation for the fandom's object in order to sustain itself, necessitating at least a degree of "genuinization."

\section{Conclusion}

The story of FK Slutsk Worldwide is not only a curious anecdote showing the unprecedented effects of a global pandemic on international sport fandom, but also a case study of how an ironic sport fandom functions online under these circumstances. By tracing the changes in the Facebook group's content over the first months of its existence, I have identified three key stages in the its development.

During the initial period following the group's formation, which I term the novelty stage, much of the conversation in the group was humorous in nature and revolved around the fans' recognition of the peculiar and incongruous circumstances that brought them together. The group displayed the features of an ironic fandom without a strong identity, whose irony mostly targeted the novelty of an 
international community rooting for a previously unknown club that plays in an obscure league and happens to have a semi-obscene-sounding name.

Yet, in a few weeks, the community found itself moving beyond the "Slutsk/ sluts" jokes and developing a deeper community identity with its own in-jokes and insider references. During this identity formation stage, FK Slutsk Worldwide began to display more similarities with conventional football fandoms, with the target of its humor changing accordingly. The community also increasingly engaged in dialogue with both the club's management and its local fans.

Finally, as the first wave of the pandemic receded and football leagues around the world began to reopen, the community reached the third stage: those who were there for amusement alone left, while those who had developed a genuine attachment to the club stayed and continued to function as a bona fide online fandom.

The story of FK Slutsk Worldwide, then, is a story of an ironic fandom gradually transforming into a genuine one, driven by the inherent instability at its core: the tension between ironic distance and the need for a more stable identity rooted in shared appreciation.

As a case study, this account cannot be generalized: I do not claim that every ironic fandom will inevitably follow the same trajectory as FK Slutsk Worldwide did. I do, however, believe that the tension between the irony and the fandom is present in many ironic fandoms, and investigating whether and how it is resolved in other contexts can contribute to a better understanding of the concept of ironic fandom itself.

\section{References}

Adetunji, Akinbiyi. 2013. A discursive construction of teasing in football fandom: The context of the South-Western Nigerian Viewing Center. Discourse \& Society 24(2). 147-162.

Ang, len. 2006. Dallas and the ideology of mass culture. In John Storey (ed.), Cultural theory and popular culture: A reader, 265-274. Harlow: Pearson Education Limited.

Bailey, Steve. 2005. Media audiences and identity: Self-construction in the fan experience. Basingstoke and New York: Palgrave Macmillan.

Baym, Nancy K. 2000. Tune in, log on: Soaps, fandom, and online community. Thousand Oaks \& London \& New Delhi: Sage.

Baym, Nancy K. 2007. The new shape of online community: The example of Swedish independent music fandom. First Monday 12(8). https://firstmonday.org/ojs/index.php/fm/article/view/ 1978/1853 (accessed 9 July 2020).

Bekkering, Denis J. 2016. Fake religions, politics and ironic fandom: The Church of the SubGenius, Zontar and American televangelism. Culture and Religion 17(2). 129-147.

Bekkering, Denis J. 2018. American televangelism and participatory cultures: Fans, brands, and play with religious "fakes". London: Palgrave Macmillan. 
Bell, John, lan Somerville \& Owen Hargie. 2020. The structuration of a sporting social system? Northern Ireland fans, football for all and the creation of the Green and White Army. International Review for the Sociology of Sport 55(7). 975-990.

Benigni, Vince, Lance Porter \& Chris Wood. 2009. The rant: How online fan culture is revolutionizing college football. Journal of Electronic Communication 19(3). 1-13.

Benkwitz, Adam \& Gyozo Molnar. 2012. Interpreting and exploring football fan rivalries: An overview. Soccer \& Society 13(4). 479-494.

Berlyne, Daniel E. 1972. Humor and its kin. In Jeffry Goldstein \& McGhee Paul (eds.), The psychology of humor: Theoretical perspectives and empirical issues, 43-60. New York and London: Academic Press.

Cleland, Jamie \& Kevin Dixon. 2015. 'Black and whiters': The relative powerlessness of 'active' supporter organization mobility at English Premier League football clubs. Soccer \& Society 16(4). 540-554.

Dyal, Mark Wayne. 2012. The ultras, the state, and the legitimacy of violence. Urban Anthropology and Studies of Cultural Systems and World Economic Development 41(1). 75-106.

Dynel, Marta. 2016. “I has seen Image Macros!” Advice animals memes as visual-verbal jokes. International Journal of Communication 10. 660-688.

Edwards, S. M. 2007. Private enterprise: the country diary of an Edwardian lady and female fan communities: The country diary of an Edwardian lady and female fan communities. Journal of Popular Culture 40(2). 249-271.

Frederick, Evan L., Choong Hoon Lim, Clavio Galen \& Patrick Walsh. 2012. Why we follow: An examination of parasocial interaction and fan motivations for following athlete archetypes on twitter. International Journal of Sport Communication 5(4). 481-502.

Haig, Francesca. 2014. Guilty pleasures: Twilight, snark and critical fandom. In Wickham Clayton \& Sarah Harman (eds.), Screening twilight: Critical approaches to a cinematic phenomenon, 11-25. London and New York: I.B. Tauris.

Howard, Robert Glenn. 2008. The vernacular web of participatory media. Critical Studies in Media Communication 25(5). 490-513.

Jenkins, Henry. 2006. Fans, bloggers, and gamers: Exploring participatory culture. New York and London: New York University Press.

Jones, Katharine W. 2008. Female fandom: Identity, sexism, and men's professional football in England. Sociology of Sport Journal 25(4). 516-537.

Kytölä, Samu. 2012. Peer normativity and sanctioning of linguistic resources-in-use-on nonstandard Englishes in finnish football forums online. In Blommaert Jan, Sirpa Leppänen, Päivi Pahta \& Tiina Räisänen (eds.), Dangerous multilingualism: Northern perspectives on order, purity and normality, 228-260. London: Palgrave Macmillan.

Lukashenko, Aleksandr. 2020. Ya chelovek nep'yushchiy, no v posledneye vremya v shutku govoryu, chto vodkoy nado ne tol'ko ruki myt' [Alexander Lukashenko: I am a non-drinker, but lately I have been jokingly saying that you should not only wash your hands with vodka]. Stolichnoe televidenie - STV. March 16, 2020. http://www.ctv.by/aleksandr-lukashenko-yachelovek-nepyushchiy-no-v-poslednee-vremya-v-shutku-govoryu-chto-vodkoy-nado (accessed 22 July 2020).

Martin, Rod A. \& Thomas Ford. 2018. The psychology of humor: An integrative approach. London: Academic Press.

McCormack, Ange. 2020. Missing sport? These Adelaide soccer fans have quietly sparked a cult following of a league in Belarus. ABC News. 14 May 2020. https://www.abc.net.au/triplej/ programs/hack/adelaide-soccer-fans-rally-around-obscure-team-in-belarus/12248408? 
fbclid=IwAR33VfjvpZEc-MwpGWPFrbGRUGYONcQPb2txftwmnFDB3zUS50Ez-bhGEJo (accessed 5 June 2020).

McCormick, Casey J. 2018. Active fandom: Labor and love in the whedonverse. In Booth Paul (ed.), A companion to media fandom and fan studies, 369-384. Oxford: John Wiley \& Sons.

McGraw, A. Peter \& Caleb Warren. 2010. Benign violations: Making immoral behavior funny. Psychological Science 21(8). 1141-1149.

Parganas, Petros, Christos Anagnostopoulos \& Simon Chadwick. 2015. 'You'll never tweet alone': Managing sports brands through social media. Journal of Brand Management 22(7). 551-568.

Parnell, Daniel, Widdop Paul, Alex Bond \& Rob Wilson. 2020. COVID-19, networks and sport. Managing Sport and Leisure. 1-7. https://www.tandfonline.com/doi/full/10.1080/ 23750472.2020.1750100?casa_token=KPFt5IIXVBEAAAAA\% 3AG7iuCyWIXB98flvlp8YeyCP4Bo_ G1wuoJVc1UdtCvkwm8rRHkfgFUtcHpXkuQxG4dSRzfSpxdEY (accessed 9 July 2020).

Rivers, Damian J. \& Andrew S. Ross. 2019. "This channel has more subs from rival fans than Arsenal fans": Arsenal Fan TV, football fandom and banter in the new media era. Sport in Society. 1-20. https://www.tandfonline.com/doi/full/10.1080/17430437.2019.1706492? casa_token=DtXaHwdlxE8AAAAA\%3A12N30q3Q97KHn1MPSiQuhTeXxvv2iwKW6gE7Cz NtFbX7czJSLkeir1iRyBZmoSJ-8GxaSugoZAQ (accessed 9 July 2020).

Ruddock, Andy, Brett Hutchins \& David Rowe. 2010. Contradictions in media sport culture: The reinscription of football supporter traditions through online media. European Journal of Cultural Studies 13(3). 323-339.

Shifman, Limor. 2014. Memes in digital culture. Cambridge, MA: MIT Press.

Shifman, Limor \& Mike Thelwall. 2009. Assessing global diffusion with web memetics: The spread and evolution of a popular joke. Journal of the American Society for Information Science and Technology 60(12). 2567-2576.

Skey, Michael, Maria Kyriakidou, Patrick McCurdy \& Julie Uldam. 2016. Staging and engaging with media events: A study of the 2014 Eurovision Song Contest. International Journal of Communication 10. 3381-3399.

Spinda, John S. W., Adam C. Earnheardt \& Lawrence W. Hugenberg. 2009. Checkered flags and mediated friendships: Parasocial interaction among NASCAR fans. Journal of Sports Media 4(2). 31-55.

Sullivan, Gavin B. 2002. Reflexivity and subjectivity in qualitative research: The utility of a Wittgensteinian framework. Forum Qualitative Sozialforschung/Forum: Qualitative Social Research 3(3). 20.

Thomas, Lyn. 2009. The Archers: An everyday story of old and new media. Radio Journal: International Studies in Broadcast \& Audio Media 7(1). 49-66.

Turner, Simon. 2016. Yaoi online: the queer and affective practices of a yaoi manga fan community. London: Birkbeck, University of London PhD Dissertation.

Waliaula, Solomon \& Okong'o Joseph. 2020. The Covid-19 pandemic and the social life of English Premier League Football Fandom in Eldoret, Kenya. Soccer \& Society. 1-10. https://www. tandfonline.com/doi/full/10.1080/14660970.2020.1772241?casa_ token=tJGK9F9MCesAAAAA\%3AOkkPY_eRZ2wRDFFOVRMnAo1XE1a2xePgHRhBxBU-MdLMBvOfNZDuxfxWWVJy2kSq_7qopm0aXY (accessed 9 July 2020).

Whetmore, Edward Jay \& Alfred P. Kielwasser. 1983. The soap opera audience speaks: A preliminary report. Journal of American Culture 6(3). 110-116. 
Yuksel, Mujde \& Lauren I. Labrecque. 2016. “Digital buddies”: parasocial interactions in social media. Journal of Research in Interactive Marketing 10(4). 305-320.

Yus, Francisco. 2019. Multimodality in memes: A cyberpragmatic approach. In Patricia Bou-Franch \& Pilar Garcés-Conejos Blitvich (eds.), Analyzing digital discourse: New insights and future directions, 105-131. Cham: Palgrave Macmillan.

\section{Bionote}

\section{Anastasiya Fiadotava}

Department of Folkloristics, Estonian Literary Museum, Tartu, Estonia anastasiya.fiadotava@folklore.ee

Anastasiya Fiadotava, PhD, is a junior researcher at the Department of Folkloristics of the Estonian Literary Museum and the Center for Excellence in Estonian Studies, Tartu. Her fields of interest include folkloristics, humor studies, and family lore. 